\title{
Reading Akhmatova: on the Pathway to Finding Self
}

\author{
Galina P. Mikhailova* \\ Vilnius University \\ 3 Universiteto Str., LT-01513 Vilnius, Lithuania
}

Received 16.02.2015, received in revised form 19.04.2015, accepted 09.06.2015

Based on P. Ricoeur's theory of reading, the article provides a literary solution to the problem of self-identification, leading to the issue of a poet's "narrative identity". It is proved by the analysis of "Reading "Hamlet"”, Anna Akhmatova's early poem. Analysis of Akhmatova's refiguration and study of this poetic configuration have showed the poet's desire to achieve selfhood by identifying the life-world with Shakespeare's texts. The article presents the comparison of cultural meanings, characteristic to Shakespeare's characters (Ophelia and Hamlet) from the point of view of Russian and European readers, Anna Akhmatova's predecessors and contemporaries. Special attention is paid to possible identification of Akhmatova with Elizabeth Siddal, one of the characters of the European cultural field, and to her fictional image of herself as Shakespeare's Ophelia. Interpolating certain meanings of the read and interpreted cultural texts on the predicates of her own life situation of 19031912, Akhmatova, first of all, clarifies her relationships with Nikolai Gumilev and solves the problem of preserving her own identity.

Keywords: Akhmatova, Gumilev, Hamlet, Ophelia, Rosetti, Siddal, Ricoeur, identity, life-world.

DOI: 10.17516/1997-1370-2015-8-7-1405-1418

Research area: philology.

\section{Introduction}

After T.V. Tsiv'ian's article, written quite a long time ago (Tsiv'ian 1989), the study of the reflection of Akhmatova's lyrical subject in the mirrors of "the others" is one of the common principles in the analysis of the poet's work. In her later work Tsiv'ian dwelt upon the articulation of Akhmatova's mirror theme in "the formation of self through the other" (Tsiv'ian 2001, 11). In further studies of Akhmatova's work the idea of reflectivity is linked to a greater or lesser degree with the search for identity by both Akhmatova's lyrical heroine and the author herself ${ }^{1}$. In this article I shall not focus on the concepts of "counterpart" and "mirror reflection" in Akhmatova's work. To analyze Akhmatova's pathway to self-awareness and self-realization I shall base on her reading and interpretation of some cultural texts, or, in other words, a literary solution of self-identification problem, which makes it possible to dwell on "the modality in which one understands him/ herself through understanding texts, i.e. one is able to associate the stories read to his / her

(C) Siberian Federal University. All rights reserved

* Corresponding author E-mail address: galina.michailova@flf.vu.lt 
own life ...” (Tetaz 2012, 106). Thus, remaining within the framework of self-identification problem, the analysis will unfold in the direction of Paul Ricoeur's reflexive tradition.

\section{Theoretical prerequisites}

The issue of self-understanding, mediated by cultural signs, symbols and texts (a sort of "mirrors") was in the focus of Ricoeur's interest: “...Il n'est pas de compréhension de soi qui ne soit médiatisée par des signes, des symboles et des textes; la compréhension de soi coïncide à titre ultime avec l'interprétation appliquée à ces termes médiateurs (Ricoeur 1986, 29) ${ }^{2}$. In this case the reading range and literary characters, selected for self-understanding, are of a certain value. They set a personality's “individual style of existence" (Tetaz 2012, 114). Thus, Ricoeur writes, “...je ne suis pas l'auteur quant à 1 existence, je m'en fais le coauteur quant au sens" (Ricoeur, 1990, 191) ${ }^{3}$. The problematic character of own existence authorship, Ricoeur writes about, is in the "wills" of the "life-world" independent from an individual: “... I inherit from the past of my family, my city, my tribe, my nation, a variety of debts, inheritances, rightful expectations and obligations. These constitute the given of my life, my moral starting point...." (MacIntyre 2007, 220). Similar entities of being, controlling an individual, fit into his story about "what (but not who!) is he" (Tetaz 2012, 115). Access to selfhood ${ }^{4}$ (to who am I?) and to interpretation of own life situations is provided by the opportunity to fill one's existence with the meanings derived from narrative resources available to self: “... for me, the world is the whole set of references opened by every sort of descriptive or poetic texts I have read, interpreted and loved. <..> Indeed, we owe a large part of the enlarging of our horizon of existence to poetic works" (Ricoeur 1998, 98). In the process of reading, living through a variety of opportunities offered by the fictional worlds the reader's self learns him/herself and thus changes interpreting of "the proposing of a world that I might inhabit and into which I might project my ownmost powers" (Ibid, 99) in the text.

\section{The object of the analysis and problem statement}

It is worth while focusing on two issues: 1 . William Shakespeare's "Hamlet" as a cultural symbolicresourcethroughwhichAkhmatovareads her life and constructs her identity; 2. "Reading "Hamlet"", Akhmatova's poetic narrative of self, positioning self-understanding. I assume that the conclusion, the analysis of Akhmatova's refiguration and poetic configuration ${ }^{5}$ will result in, will be the following: Akhmatova's lifeworld, designated by Hamlet's text, appears to be different and "discovers intelligibility it has lacked before” (Tetaz 2012, 106).

\section{"Reading "Hamlet"" in the context of Russian and European "Shakespeariana"}

In the memoirs of Akhmatova's contemporaries the statements about her interest in a personality and creative work got the status of locus communis ${ }^{6}$. This passion was dwelt upon in her "Zaspisnye knizhki" ("Notebooks"), 19581966. One of evidences that there were no rivals to Shakespeare as an object of her reading and thought runs: "In summer 1915 in Slepnevo I read Racine. (Now <in> 1965 these are Donne and Elliot. And always Shakespeare)" (Zaspisnye knizhki 1996, 667). It is also important that Akhmatova's affection to Shakespeare revealed that type of an acmeistic creative (producing) reader which was exactly characterized by Annenskii: "a poet's reading is already creativity in itself" (Annenskii 1979, 5). The following fact is worth mentioning here: in 1957 Akhmatova 
planned to write a book with the second part "Marginalia", containing notes about Shakespeare (Zaspisnye knizhki 1996, 667).

Akhmatova also read Shakespeare in the original". As for the sixteen lines of "Reading "Hamlet"", they were written when Akhmatova did not know English (1909) ${ }^{8}$ :

\section{1}

A lot by the graves was a dusty hot land;

The river behind -- blue and cool.

You told me, "Well, go to a convent,

Or go to marry a fool..."

Princes always say that, being placid or fierce,

But I cherish this speech, short and poor -

Let it flow and shine through a thousand years,

Like from shoulders do mantels of fur.

2

And, as if in wrong occasion,

I said, "Thou," else...

And an easy smile of pleasure

Lit up dear face.

From such lapses, told or mental,

Every cheek would blaze.

I love you as forty gentle

Sisters love and bless 9 .

(Akhmatova, 1990: I, 24)

Their title points to the text, generating the poems (the tragedy "Hamlet"), and the way of the source interpretation (reading). In the frame of Ricoeur's hermeneutics the poem is a phenomenon of a special interest. Firstly, it contains the traces of prefiguration. They are obvious in the title with its reference to the "world of actions which got already configured by the narrative" (Ricoeur, 1989, 209), to "pre-understanding common to the poet and the reader" (Ibid., 79). Secondly, the title establishes a productive nature of the poem's memetics, the poem representing the results of refiguration process - Akhmatova's reading "Hamlet".
Thus, the name of the poem states that "productivity of meaning" (Iu. Kristeva) which emerges in the process of reading "Hamlet". On the one hand, "Reading "Hamlet"" is a copy of consciousness of Akhmatova as a reader, interpreting Shakespeare's tragedy "as some outline for reading" (Ricoeur, 1989, 94). On the other hand, according to Paul Ricoeur's theory of reading, in imagination mode Akhmatova's reading self is identified with certain characters of Shakespeare's tragedy.

A poetic diptych as a specimen of interpretation of Shakespeare's plot in the process of the author's lyrical self-identification (the author's self as Ophelia) ${ }^{10}$ can be brought into correlation with the generalization of the "Hamlet" love plot in artistic and philosophical minds of the Silver Age representatives. Reading and interpretation of Shakespeare's texts in the culture of the turn of the century had its own specificity. A few examples below provide the evidence to this.

In the article "What is poetry?" (1903) I.F. Annenskii stated: "No great work of poetry remains completely interpreted in the course of the poet's life, whereas his symbols imprint the issues, giving rise to human thought, for a long time. Not only a poet, critic or artist, but even a viewer and a reader everlastingly create Hamlet" (Annenskii 1979, 205). Annenskii based his article "The issue of Hamlet" (1909) "on the correlation of the tragedy's firmly completed texture and the endless liveliness of its perception" (Podolskaia 1979, 517).

L.S. Vygotsky, a future founder of culturalhistorical theory of the human psyche, stated in his manuscript in 1915-1916: "Once the work of art is created, it is separated from its author, it is just an opportunity that the reader takes" (Vygotsky 1987, 252). Vygotsky refers to the concept of Iu.I. Aikhenwald, an adept of the "readers' criticism, the author of a series of essays about 
Shakespeare (1908-1910), and to the point of view of A.G. Gornfeld, a literary critic: "Every new reader of "Hamlet" is a sort of its new author" (Ibid, 253). In the article "About Shakespeare and the drama" (1906) L.N. Tolstoy also posits himself as "a reader free from suggestion" (Tolstoy 1983, 278). Thus, the Russian "map of rereading" (H. Bloom) "Hamlet" in this epoch is marked by fundamental subjectivity.

As for the characters of the tragedy, the readers' evaluation of the image of Hamlet ranged from that of a "sensual and even secretly voluptuous» egoist, according to I.S. Turgenev (Turgenev 1980, 330), to a skeptic "humbled by the ideation of life" who has no feelings of love, according to L.I. Shestov (Shestov 1911, 82). The perception of Ophelia was not varied. In the preface to the translation of "Hamlet" A. Kroneberger (1899) summarizes the points of view on Shakespeare's heroine prevalent in the minds of readers and critics: “... For every reader Ophelia remains a very nice creature, arousing involuntary pity to herself but is, nevertheless, hardly understood and seems, for all her completeness, something vaguely drafted (Hamlet 1899, 143).

This interpretation of Ophelia's image is traditional. V.G. Belinskii in his article of 1838 "'Hamlet", a Drama Shakespeare. Mochalov and the Role of Hamlet" stated that Ophelia is “... a creature that is completely alien to any strong stunning passion yet born for a quiet and calm but deep feeling ..." (Belinskii 1959, 203). I.S. Turgenev in his speech "Hamlet and don Quixote" (1860) noted that Ophelia is “... an innocent being, clean as holiness" (Turgenev 1980, 330). V. Kablukov's idea that "the poetry of the early XX applied ... the principle of mirror "copying" to William Shakespeare's "Hamlet", turning the images of the play in the opposite direction" (Kablukov 2008) is true, in my opinion, only in connection with the poetry of Marina Tsvetaeva and partly Akhmatova. By using the words of James Joyce's character of the novel "Ulysses" "But his (Shakespeare's) boywomen are the women of a boy. Their life, thought, speech are lent them by males" (Joyce $2003)^{11}$ I will say that both poetesses destroyed the asymmetry of "Hamlet" gender structure and acted, in compliance with the feminist criticism terminology, as "resisting readers", "expanding" and "writing" the image of Ophelia in accordance with their poetic mythology, artistic temperament and gender.

Personal interest of the readers of "Hamlet" is obviously inspired by the fact that Shakespeare's text shows existential reality correlated to the different time layers, i.e. the process of reading "Hamlet" leads to crystallization of what Ricoeur termed the "refiguration of temporary experience by constructing intrigue" (Ricoeur 1989, 87).

In light of the above it can be possible to interpret the lines of the first verse of Akhmatova's cycle:

Princes always say that, being placid or fierce,

But I cherish this speech, short and poor -

Let it flow and shine through a thousand years,

Like from shoulders do mantels of fur.

(the italics are mine. - G.M.)

According to H. Arendt's definition, “... "overcoming the past" may take the form of ever recurring story-telling till the meaning of the events is alive - and this meaning may be preserved for a very long time" (Arendt 2003, 32). Four verses cited above are a sign of adherence to the traditions of the perception of Shakespeare's "Hamlet" (and the image of Ophelia, in particular) as an imperishable element of the "world significant poetic text". It is evident in the form of a hidden reference (in italics) to "Ophelia" by Arthur Rimbaud whose poetry Akhmatova knew by heart: 
Voici plus de mille ans que la triste Ophélie

Passe, fantôme blanc, sur le long fleuve noir; Voici plus de mille ans que sa douce folie

Murmure sa romance à la brise du soir.

(Rimbaud 1993, 27. Italics is mine. - G.M. $)^{12}$

It is worth while noting that those works of Russian fin du siècle, the images and themes of which go back to "Hamlet-Ophelia"line, explicate the motives other than Akhmatova's ones. These are the motives of the heroine's madness and death (Ophelia's songs, Ophelia's flowers, drowned Ophelia). These are the texts by M. Lokhvitskaia,

A. Blokh, I. Annenskii, B. Livshits, V. Briusov, I. Severianin, B. Pasternak, M. Tsvetaeva. Whether it was inspired by the poetic culture (for example, A. Fet's poem of 1846 "Ophelia gibla i pela..." (“Ophelia was dying and singing ...") or Rimbaud) or the pictorial tradition is the subject of a special research. But one of the aspects of a possible research seems to be important.

\section{"Reading "Hamlet"":}

Akhmatova - Gumilev

vs Dante Gabriel Rossetti Elizabeth Siddal

Images of Ophelia either distraught or sunk can be seen in the English Pre-Raphaelites' paintings (J.E. Millais, A. Hughes, D.G. Rossetti, J.W. Waterhouse). Passion for Pre-Raphaelites is a characteristic feature of the modernist art of the early XX century. Thus, Dante Gabriel Rossetti, for example, was very popular in Russia of that epoch. This makes us assume that mentioning Shakespeare (R. Timenchik) in Akhmatova's lyric diptych is in citation overtones of D.G. Rossetti... and Nikolai Gumilev. Sharing Ricoeur's belief that one who can read his / her life in the light of cultural works is able to tell about him /herself. It should be noted here that "Reading "Hamlet"” is written in the period between Akhmatova and Gumilev's betrothal (1907) and wedding (1910) which was very difficult concerning their relations.

References to Rossetti in connection with Akhmatova's cycle may not seem motivated ${ }^{13}$. However, some facts are intriguing. It is known that Gumilev saw the resemblance between Akhmatova and "Monna Pomona", Rossetti's watercolor ${ }^{14}$. Within gender studies Rossetti's portraits of women are interpreted as representations of a "male (patriarchal) view" on a female identity: "The opposition between Rossetti's deviant femmes fatales and mistressstunners and the ideal "Damsel of the Sanct Grael" quite literally represent this opposition between "a monster and an angel" and leave no categorical identity outside these entities for women to take on" (Maloney 2012). From this point of view, "even for some "modern" viewers of the relatively sexually-liberated age of today feel uncomfortable when looking at Monna Pomona; she is almost too confident, too easy, and too uncontrolled for us to safely enjoy" (Ibid.).

In order to draw some conclusions on Gumilev's identification of Rossetti's watercolor with Akhmatova it should be added that Akhmatova believed Gumilev's cycle "Beatrice", which is opened with the poem written in 1906 and alluding to Rossetti's painting "Beata Beatrix", as well as his sonnets to be addressed to her (Stikhi i pisima... 1986, 198, 210-211). The image of "Beata Beatrix" heroine integrated a sublime spirituality of Dante's Beatrice and a disastrous seductiveness of femme fatales, that fragile balance between "angel" and "monster" developed by the PreRaphaelites. The lyrical heroine of the "Beatrice" cycle embodies practically the same canon of feminine identity. According to Akhmatova, she was everything - "Margarita who was in love with Mephistopheles", "a female vamp in the corner", "a poisoner", “a Kiev witch from Lysaia mountain” (Zapisnye knizhki 1996, 152). In her 
verses Akhmatova dramatizes the ambivalent dichotomy between two possible female images a traditional patriarchal ideal and a feminist ideal. From this point of view Iu.I. Aikhenval'd's review on Akhmatova's collections of poems ("Vecher" ("Evening"), "Chetki" ("Beads"), "Belaia staia" ("White flock") and "Podorozhnik" ("Plantain") is significant. He noticed the phenomenon of the "image of the female soul who has accepted love as poison, disease, and suffocation", "a sufferer" of love who "wants to be tamed, conquered..." but experiences "some minutes when her humility fades away and is replaced by the reaction of unrestrained and violent protest" in them (Aikhenval'd 2001).

It can be assumed that the acts of Akhmatova's comprehension of Rossetti's paintings (and possibly sonnets) and a dramatic life story of Rossetti and Elizabeth Siddal, his student, muse and wife, mediated by these works, refigurated her self, producing a model for interpretation of her own experience which had the points of convergence with the experience of Rossetti and Siddal.

Lizzie Siddal, a model known among the artists, married Rossetti who was "gifted, handsome, intellectual $<\ldots>$ and also the hero of the little art group to which he belonged" (Hubbard 1916, 255). Akhmatova, a "stylish St. Petersburg poetess" similarly linked her fate with a traveler, poet, and literary groups' organizer. According to Akhmatova, they both had "a very long and terrible life" in the years prior their marriage (Zapisnye knizhki 1996, 220). Both went beyond social ideas of femininity, peculiar to their time: Lizzie's behaviour and moral standards were far from being exemplary as required by the ethics of the Victorian era (Pina 2004). Young Akhmatova "did not impress the "virtuous" dwellers of musty, very ill-mannered and stupid Tsarskoye Selo". She did not recognize "any violence against her neither physical nor psychological” (Sreznevskii
1991, 6, 12). Health problems (tuberculosis) as well as instability of the psyche, exaltation and tendency to depression were also common.

Akhmatova's letters of 1906-1907 can serve illustrations of such conditions: "I have heart neurosis caused by worries, constant torments and tears" (Akhmatova 1990: II, 178); “... how pathetic and unwanted I am. Wanted by no one and nowhere. To die is easy. [...] In Evpatoria I hung myself on the nail but the nail popped out of the limestone wall ..." (Ibid., 179); "I became evil, capricious, unbearable. [...] I hate myself, despise, I can't stand the lies entangling me...” (Ibid., 183). Excruciations were provoked by undivided love, the memory of which haunts Akhmatova who married Gumilev who pained with passion and her refusals. In February 2, 1907 she writes in her letter to S.V. von Stein: "Do you remember V. Briusov's lines about an old friend and sister, crucified to torments and whom the hand was given to be saved? And I gave him a hand. But only God and you know what was in my soul ... $<\ldots>$ I am not writing anything and never will. I have killed my soul, and my eyes are created for tears, as Iolanta says. Or prophetic Cassandra Schiller. Do you remember her? One facet of my soul is adjacent to a dark image of this prophetess who was great in her suffering. But I am far from being grand" (Ibid., 181-182)

On the whole, Akhmatova's psychological state in the course of one decade (the end of 1903 acquaintance with Gumilev, 1910 - wedding, 1912 - the end of the relationships with Gumilev) resembled the atmosphere of D.G. Rossetti and Elizabeth Siddal's life during approximately the same number of years: in 1849 Lizzie becomes one of the leading models of Pre-Raphaelite Brotherhood, in 1860 she marries Rossetti and in 1862 she dies. The atmosphere of these relations was reconstituted by E. Hubbard, quoting one of Rossetti's letters: "How truly she may say, 'No man cared for my soul'. I do not mean to take 
myself an exception, for how long have I known her..." (Hubbard 1916, 265).

Evidently there is no absolute certainty that Akhmatova's creation of herself as a subject these years developed like identification with Lizzie Siddal. However, it is possible that the process of "reading" "Rossetti - Siddal text" was a way to interpret the present and look into the future, a sort of "prospective articulating" (Ricoeur 1990, 193).

It is worth while quoting an extract from Gumilev's letter dated April 9, 1913: “Dear Anya, I know you neither love nor want to understand it, but I'm happy and feel motivation for strengthening and putting forward a man in me as your femininity is getting more and more apparent for me" (Gumilev 1991, 236). Two points arouse interest in this statement: Gumilev's position and that of Akhmatova as he stated it. For Gumilev a woman is a man's Other, reflecting his masculinity that also presupposes creative energy. Yet Akhmatova refused this manifestation of self ("you neither love nor want to understand it") that was very common in the circle of silver age aristocracy of talent. Viacheslav Ivanov's words, concerning L.D. Zinovieva-Annibal who resigned to the "negative" image, prove this: "We have found ourselves through each other. It was not only me who exposed himself for the first time and easily and confidently realized being a poet, but her as well" (Mikhailova 1994). This could be compared with the notes of Akhmatova in a later period of her poetic work: “... I stood up for myself. I also had to be myself but not a follower, a myrrh bearer ..."; "all my protest ... was in an instinctive desire to save myself, my pathway in art, my individuality"; “[Gumilev] didn’t exert the slightest influence on the girl who was with him and whom he adored with a huge tragic love for so long (or, probably, this was the reason)" (Zapisnye knizhki 1996, 233, 272, 625).

\section{"Reading "Hamlet"": self-discovery through Ophelia}

Is my long excursus in Victorian period related to Akhmatova's "Hamlet" poem? It definitely is due to two facts. The first one: Lizzie Siddal posed for J.E. Millais when he created his famous "Ophelia" (1851). The second one: the assumption that Akhmatova had the idea of Shakespearean sketches by Rossetti ${ }^{16}$. Rossetti's drawing in pen (1858) and watercolour (1866) "Hamlet and Ophelia" are of a special interest here as they illustrate the situation in the prayer room: the return of the gifts accompanied by the dialogue between Hamlet and Ophelia in Scene I of Act III. The words of this extract from Shakespeare's "Hamlet" determined a structural formant of the first verse in Akhmatova's cycle.

Akhmatova broke the tradition of poetic interpretation of those scenes in "Hamlet" which complete Ophelia's storyline, and namely the scenes of madness and death. These tragic episodes will appear in Akhmatova's lyric poetry only decades later - in "Polnochnye stikhi" ("Midnight verses"), the cycle of the 1960s. In this very early cycle only an unassuming landscape sketch in the first verse can be interpreted as the text containing reference points (a cemetery and a river) to Ophelia's forthcoming fate or to the theme of death hovering over all the storylines of Shakespeare's tragedy.

It is necessary to refer directly to the text "Reading "Hamlet"" as a whole in two parts which are linked with the quotation (...Get thee to a nunnery, go, farewell. Or if thou wilt needs marry, marry a fool) and the reminiscence (I love you as forty gentle sisters love and bless) from "Hamlet", and namely the Prince's words in Act III $^{17}$ and Hamlet's challenge thrown down at Laertes in the scene of Ophelia's funeral in Act $\mathrm{V}^{18}$. Some constants of Akhmatova's image of Ophelia can be specified in its comparison with Shakespeare's image. We assume that Akhmatova's lyrical 
heroine "remembered" not only Hamlet's vision of Ophelia's future (monkery or specific marriage) but also Shakespeare's context of cruel, categorical suggestions. This context is important for understanding the hero torn by contradictory emotions and introspection. The hero's state was defined by Annenskii in 1907 the following way: "Ophelia torments Hamlet as the shadow of that greasy bed with skinny Claudius, kissing her old mother, relentlessly haunts her. $<\ldots>$ For Hamlet Ophelia died not because she is a weak-willed daughter of the old fool and even not because she is a living thing he would like to sell for a higher price but because marriage cannot be beautiful and the girl's noble beauty should die as a lonely beauty, under a black veil and by votive candles' melting wax" (Annenskii 1979, 168-169).

ThemeaningofthesecondpartofAkhmatova's cycle is constructed by the opposition of the pronouns thou and you. Personating in Ophelia and as if obeying to the state of affairs that "... the singular personal pronoun in Shakespeare's works often creates some emotional coloring and thereby renders the relation of individuals to each other" (Morozov 1954), Akhmatova starts a dialogue with an offended heir and a lover, tortured by suspicions, on equal terms. For this she uses a familiar address: "I said, "Thou,"”. The four verses of the poem, following it, contain a new addressee's psychological reaction: from a smile (of distrust? joy?) that flashed on his face to a sparking (with passion? hope for understanding?) gaze. The final words are a perversion of Hamlet's words at Ophelia's grave voiced by the lyric self. A mad man's love metaphor forty thousand brothers / Could not, with all their quantity of love, / Make up my sum loses its pretentious hyperbolic expression when pronounced by Akhmatova's Ophelia. Hamlet's "sense of a phrase" (I. Turgenev) takes the verbal form of "joy and consolation" (L. Shestov): I love you as forty gentle sisters love and bless.
Predictability of these last verses is provoked by Ophelia's character. She was described by G. Brandes, a literary critic and Akhmatova's contemporary, engaging in controversy on "sensual" interpretation of Ophelia's image, wrote: "She is a gentle, submissive creature with no strength to resist; she is a soul that loves but without passion, giving a woman the independence of action. <..> She remains a witness to his depressed mood, not knowing its causes" (Brandes, 1997) (italics are mine. G. M.).

Semantics of Akhmatova's suspension points (one of the forms of her "poetics of uncertainty"), introducing a gentle consolation, is very important. Akhmatova's three dots sign is always emotionally coloured. In this case it chastely marks "the dynamics of the unnamed" (L. Ginzburg) - a probable erotic development of "Ophelia - Hamlet" story-line. It also marks the pause necessary for perception of the non-erotic, "sister-like" concluding words in which the voices of the poem character (Ophelia), explicit character (Ophelia's self) and the implicit author clearly merge ${ }^{19}$. This single voice responses to the torture of Hamlet's physical existence with a spiritual verbal gesture with the semantics of perfect completeness, harmony resulting from the sacred symbolism of number forty.

The conclusion drawn generally coincides with V. Kablukov's opinion based on a different idea, and namely the comparison of Akhmatova's cycle with Pushkin's "Ty i vy" ("Thou and you") poem: “... In Akhmatova's poetry physical nature of the universe is a taboo. Love of a "sister" is purely spiritual and hyperbolical with a numeral" (Kablukov 2008). Similarity of the research result is not surprising: cultural atmosphere of silver age was filled with the motives of the opposition of Aphrodite Urania and Aphrodite Pandemos. This can be indirectly proved by P.N. Luknitskii's notes dated August 1, 1927: “<Akhmatova $>$...doesn’t 
like physicality. Physicality is a curse of the earth caused by the first lapse of virtue, Adam and Eve... Physicality is always rude. It complicates the relations depriving them of their simplicity, bringing in lie, and deprives the relationships of their holiness..." (Luknitskii 1997, 287).

Thus, in the act of reading/transformation of Shakespeare's tragedy, at the intersection point of the worlds of "Hamlet" and Akhmatova as a reader the image of Ophelia as a conciliative, salutary power devoid of senses is constructed. Personal implications are embedded in it. It is worth while drawing the comparison with Akhmatova's letter to S.V. von Stein dated February 11, 1907: “... Gumilev is my Destiny, and I am submissively giving myself to it. <...> I swear on everything that is sacred for me that this poor man will be happy with me" (Akhmatova 1990: II, 184).

Does this humility to destiny contradict to that possible identification with proud and lonely Lizzie Siddal? From Ricoeur's point of view, losses and contradictions in self-understanding are possible on the pathway to finding self through structuring what is read. In her notes about Akhmatova L.K. Chukovskaia recollects such a dialogue: " $<$ Chukovskaia said $>$ your heroine demonstrates various ways of turning a celebration into any trouble, insult, abuse. She has somewhere to retreat... $<\ldots>$ Someone told her, "Well, go to a convent, or go to marry a fool". But this speech - this offense - is also turned into a triumph by her. $<\ldots>-$ Will you write about it someday? Anna Andreevna asked in a surprisingly plaintive voice" (Chukovskaia 2013, 153). This is the recognition of using the "strength through weakness" strategy ${ }^{20}$. It develops through explication of the lyrical self of the first part of "Reading "Hamlet" cycle, the dignity though devoid of an external attribute of power - a "mantel of fur". As for the lyrical subject of the second part of a diptych, he finds explication in getting onto familiar terms of address, in an open declaration of love, personified by Aphrodite Urania.

Akhmatova's refigurations of imaginary relations, outlined above, are caused by the collision of the world of the text and the lifeworld. They have given a chance to interpret "Reading "Hamlet" as a piece of art written in order to "clarify" the relations with Nikolai Gumilev. Identification of Akhmatova's self (the reader) with the Other (the characters of cultural texts and mythologies - Ophelia, E. Siddal) extend the sphere of her personal empirical experience, making it possible for ego to get closer to self in reflection of configuration. Later, till 1963, Akhmatova did not use Shakespeare's "Ophelia - Hamlet" model to symbolize her relationships with Gumilev or anyone else. In her middle age attention of Akhmatova-the reader was focused on another character of Shakespeare's tragedy - Queen Gertrude, but this is a story of self-understanding of a different kind.

Ref. to: Tiurina 2006, 93-98, Kolchina 2007, Mikhailova 2009, 73-89.

"There can be no self-understanding without mediation by signs, symbols, and texts; in the end self-understanding coincides with interpretation applied to these mediating categories".

"...I am not the author of \{my life $\}$ as existence; I become a coauthor of its meaning".

French "l'ipséité du soi", English "ipseity", "selfhood”.

Prefiguration, configuration, refiguration are operations involved in a fiction work creation and interaction between a fiction work and the sphere of real-life experience (Ricoeur, 1998, 264). Prefiguration (mimesis I) is based on the idea that "a human deed can be over-designated because it is already pre-designated with all modalities of its symbolic articulation" (Ibid., 99). Configuration (mimesis II) is the world of the text itself, transforming reality. Refiguration (mimesis III) is "the intersection of the text world and the world of the listener or reader..." (Ibid., 87).

6 According to A.V. Liubimova, for example, in December 1948 Akhmatova read "four thick books about Shakespeare" (op. cit.: Chernykh 2008, 434).

According to P.N. Luknitskii, Akhmatova started learning English from October 1927 г. (Chernykh 2008, 292).

8 The year 1909 is stated due to the tradition to include it in collection of poems "Vecher" ("Evening"). 
9 Transl. by T. Karshtedt.

10 The process of self-identification takes place as a result of mental contact of self with you (Hamlet). In both poems the lyrical "self", in my opinion, is comparable only with Ophelia. S.Iu. Artemova views a different opinion, correlating the lyrical "self" in the second poem of the cycle with Hamlet on the basis of only one allusion to the remark of Shakespeare's character (Artemova 2006, 134). However, the assignment of the cycle's lyrical "self” to Hamlet's reply can be interpreted as the expression of "masculine" origin in her early lyrics. This can be compared with Zh.N. Kolchina's opinion, arguing that Ophelia fits in "Akhmatova's myth about a strong-willed woman opposing inharmonious world" (Kolchina 2007, 1617).

11 Reference to Joyce is a well-grounded allusion. Akhmatova repeatedly re-read "Ulysses". R.D. Timenchik, for example, noticed poly-genetic character of lines in "El'sinorskikh terras parapet" ("Elsinore terraces parapet") in "Poem without a hero" as he noticed an allusion not only to "Hamlet" but also to the scene of Chapter I in "Ulysses"(Timenchik 2005, 670).

12 "For more than a thousand years sad Ophelia

Has passed, a white phantom, down the long black river.

For more than a thousand years her sweet madness

Has murmured its ballad to the evening breeze" (Rimbaud, 1962. Italics are mine. - G.M.).

13 In the list of artists (the draft of the letter of 1963), whom Akhmatova was addicted to, there are no names of D.G. Rossetti or other Pre-Raphaelites (Zapisnye knizhki 1996, 284). This name is also not mentioned in seemingly exhaustive book by Oleg Rubinchik (Rubinchik 2010).

14 “...young N.S. Gumilev sent an edition of Rossetti to Kiev, to Ana Gorenko, a girl who literally drove him crazy, because she looked like "Mona". There is something elusive in the face of Anna Andreevna - even now when she is 70 years old that irresistibly brings her with a heroine of Rossetti's paintings" (From G.V. Glekin's letters to A.A. Akhmatova, 2003).

15 It is noteworthy that in this letter Akhmatova constructs her self refigurating cultural texts she knew.

16 In Akhmatova Fund of the Manuscript Department of the National Library of Russia there is the London album of his drawings presented to Akhmatova by Gumilev in 1906 (Rubinchik 2003).

17 "We are arrant knaves, all. Believe none of as. Go thy ways to a nunnery $<\ldots>$ Get thee to a nunnery, go, farewell. Or if thou wilt needs marry, marry a fool; for wise men know well enough what monsters you make of them" (Shakespeare 1988, 670).

18 "I loved Ophelia. Forty thousand brothers / Could not, with all their quantity of love, / Make up my sum" (Shakespeare 1988, 684).

19 Similar "fragmentation and merging of characters and mixture of the author with his heroes" (Toporov, Tsiv'ian 1990, 428) is one of the wide-spread methods of Akhmatova's acmeistic text.

20 This is a pragmatic principle of organization of Akhmatova's artistic world in general as considered by A. Zholkovskii and L. Panova (Zholkovskii, Panova 2010, 50-71).

\section{References}

1. Aikhenval'd Iu.I. Anna Akhmatova. In: A.A. Akhmatova: Pro et contra. St.-Petersburg: RKhGI, 2001. Pp. 238-254. Available at: http://www.akhmatova.org/articles/articles. php?id=10 (accessed 10 February 2015)

2. Annenskii I.F. Knigi otrazhenii [The books of reflections]. Moscow: Nauka, 1979.

3. Arendt H. Liudi v temnye vremena [Men in dark times]. Moscow: Moscow School of Political Research, 2003.

4. Artemova S.Iu. Gamletovskie "liki" v lirike A.A. Akhmatovoi i M.I. Tsvetaevoi [Hamlet's "faces" in A.A. Akhmatova's and M.I. Tsvetaeva's lyrics]. Liki Mariny Tsvetaevoi: XIII Mezhdunarodnaia nauchno-tematicheskaia konferentsiia (9-12 oktiabria 2005 g.) (Marina Tsvetaeva's faces: XIII international scientific conference (9-12 October, 2005). M: House Museum of Marina Tsvetaeva, 2006.

5. Akhmatova A.A. Sochineniia. V 2 t. [Works. In 2 vol.] Moscow: Publishing house "Pravda", 1990.

6. Belinskii V.G. "Gamlet", drama Shekspira, Mochalov v roli Gamleta ["Hamlet", a drama by Shakespeare. Mochalov and the role of Hamlet"]. In: Belinskii V.G. Estetika i literaturnaia kritika. V 2 t. T. 1 (Aesthetics and literary criticism. In 2 vol. Vol. 1). Moscow: Khudozhestvennaia literatura, 1959.

7. Brandes G. Shakespeare. Zhizn' i tvorchestvo [Shakespeare. Life and works]. Moscow: Algorithm, 1997. Available at: http://www.lib.ru/SHAKESPEARE/brandes.txt. (accessed 14 February 2015). 
8. Chernykh V.A. Letopis' zhizni i tvorchestva Anny Akhmatovoi [Chronicle of the life and work of Anna Akhmatova]. Moscow: Indrik, 2008.

9. Chukovskaia L.K. Zapiski ob Anne Akhmatovoi. V 3 t. T. 3 [Notes about Anna Akhmatova. In 3 vol. Vol. 3. Moscow: Vremia, 2013.

10. Chukovsky K.I. Dnevnik. 1901 - 1929 [Diary. 1901-1929]. Moscow: Sovetskii pisatel', 1991.

11. Gumilev N.S. Sochineniia v 3 t. T. 3. [Works in 3 vol. Vol. 3]. Moscow: Khudozhestvennaia literatura, 1991.

12. Hamlet. Polnoe sobranie sochinenii Villiama shekspira $v$ perevode russkihk pisatelei. $V 3-k h t$. T. 3 [A full collection of William Shakespeare's works in translations of Russian writers. In 3 vol. Vol. 3]. Ed. by D.L. Mikhailovskii. Published by N.V. Gerbel'. St.Petersburg, 1899.

13. Hubbard E. (1916). Little Journeys. Great Lovers: Dante Gabriel Rossetti and Elizabeth Eleanor Siddal. Available at: http://lizziesiddal.com/Siddal-Rossetti-LittleJourneys.pdf (accessed 3 January 2015).

14. Iz pisem G.V. Glekina k A.A. Akhmatovoi [From G.V. Glekin's letters to A.A. Akhmatova] (2003). Zvezda, (10), 120-128. Available at: http://www.akhmatova.org/letters/glekin.htm (accessed 23 August 2014).

15. Joyce J. (2003). Ulysses. Project Gutenberg. Release Date: July, 2003. Available at: http:// archive.org/stream/ulysses04300gut/ulyss12.txt (accessed 22 February 2015).

16. Kabanova L.I. Kommunikatsiia v kul'ture: metodologicheskie aspekty issledovaniia [Communication in culture: methodological aspects of the research]. Petrozavodsk: Publishing House of Petrozavodsk State University, 2007.

17. Kablukov V.V. (2008). "Gamlet" Shekspira v metasoznanii russkoi liriki pervoi treti XX veka [Shakespeare's "Hamlet" in meta-consciousness of Russian poetry of the first third of the XX century]. Knowledge. Understanding. Skill, (5), Philology. Available at: http://www.zpu-journal.ru/e-zpu/2008/5/ Kablukov_Hamlet (accessed 1 August 2014).

18. Kolchina Zh.N. Khudozhestvennyi mir A.A. Akhmatovoi: Mifopoetika. Zhiznetvorchestvo. Kul'tura: Avtoreferat dissertatsii na soiskanie uchenoi stepeni kandidata filologicheskikh nauk [A.A. Akhmatova's artistic world: Mythopoetics. Life and Creativity. Culture: author's abstract of candidate of philology thesis]. Ivanovo, 2007. Available at: http://www.dissercat.com/content/ khudozhestvennyi-mir-aa-akhmatovoi-mifopoetika-zhiznetvorchestvo-kultura (accessed 23 March 2015).

19. Luknitskii P.N. Acumiana. Vstrechi s Annoi Akhmatovoi. T. II. 1926 - 1927 [Acumiana. Meetings with Anna Akhmatova. Vol. II. 1926-1927). Paris - Paris: YMCA-PRESS - Russkii put', 1997.

20. MacIntyre A. (2007). After virtue: a study in moral theory. Notre Dame, Indiana: University of Notre Dame Press. Available at: http://epistemh.pbworks.com/f/4.+ Macintyre.pdf (accessed 3 January 2015).

21. Maloney C. (2012). "More stunning than can decently be expressed": Desire and control in the stunners of Dante Gabriel Rossetti. University of Notre Dame (US, Indiana). Available at: http://genderstudies.nd.edu/assets/64255/maloney_more_stunning_web.pdf (accessed 3 January 2015). 
22. Mikhailova M.V. (1994). Strasti po Lidii [Lidiia passion]. Preobrazhenie: russkii feministskii zhurnal, (2), 144-156. Available at: http://az.lib.ru/z/zinowxewaannibal_1_d/text_0020.shtml (accessed 1 July 2014).

23. Mikhailova G.P. (2009). Akhmatova v poiskakh samosti [Akhmatova in search of self]. LITERATŪRA (Vilniaus universiteto mokslo darbai), 51 (2), 73-89.

24. Morozov M.M. Izbrannye stat'i i perevody [Selected articles and translations]. Moscow: GIKhL, 1954. Available at: http://lib.himoza.org/bin/win/SHAKESPEARE/shks_hamlet9.txt_ Piece40.06.

25. Pina S. (2004). LizzieSiddal.com. Available at: http://lizziesiddal.com/portal/ (accessed 3 January 2015).

26. Podolskaia I.I. Annenskii - kritik. Annenskii I.F. Knigi otrazhenii [Annenskii as a critic. Annenskii I.F. The books of reflections]. Moscow: Nauka, 1979. Pp. 501-542.

27. Ricoeur P. Du texte à l'action. Essais d'herméneutique II. Paris: Ed. du Seuil, 1986.

28. Ricoeur P. Soi-même comme un autre. Paris: Ed. du Seuil, 1990.

29. Ricoeur P. Vremia i rasskaz. T. 1: Intriga i istoricheskii rasskaz [Time and narrative. Vol. 1]. Moscow; St.-Petersburg: University book, 1998. Available at: http://www.philol.msu.ru/ discours/ images/stories/ speckurs/ricoeur-voll.pdf (accessed 3 January 2015).

30. Rimbaud A. (1962) Collected poems (parallel texts). Transl. by Oliver Bernard. London: Penguin, 1962. Available at: http://www.mag4.net/Rimbaud/poesies/Poems.html (accessed 23 February 2014).

31. Rimbaud A. Poésies. Paris: Bookking International, 1993.

32. Rossetti W.M. Dante Gabriel Rossetti. His family letters, with a memoir. Ellis, 1895. Vol. I. Available at: http://www.rossettiarchive.org/docs/ pr5246.a43.rad.html (accessed 3 January 2015).

33. Rubinchik O.E. (2003). Das Ewig-Weibliche v sovetskom adu [Das I-Weibliche in Soviet hell]. Toronto Slavic Quarterly, (5). Available at: http://www.utoronto.ca/tsq/05/rubinchik05.shtml (accessed 13 August 2014).

34. Rubinchik O. E. "Esli by ia byla zhivopistsem...”. Izobrazitel'noe iskusstvo v tvorcheskoi masterskoi Anny Akhmatovoi [“If I was a painter...”. Fine art in Anna Akhmatova's creative workshop]. St.-Petersburg: Serebrianyi vek, 2010.

35. Shakespeare W. The Complete Works. Compact ed. Gen. ed.: St.Wells \& G.Taylor. Clarendon Press - Oxford University Press, 1988.

36. Shestov L.I. Shekspir i ego kritik Brandes [Shakespeare and his critic Brandes]. In Shestov L.I. Sobranie sochinenii v 6 t. T. 1 (Collection of works in 6 vol. Vol. 1). St.-Petersburg, 1911. Available at: http://www.lib.ru/SHAKESPEARE/shks_shestov.txt (accessed 18 July 2014).

37. Sreznevskii V.S. Dafnis i Khloia, Vospominaniia ob Anne Akhmatovoi [Daphnis and Chloe, Reminiscences of Anna Akhmatova]. Moscow: Soviet writer, 1991. Pp. 5-19.

38. Stikhi i pis'ma. Anna Akhmatova. N. Gumilev [Poems and letters. Anna Akhmatova. N. Gumilev] (1986). Publ. by E.G. Gerstein. Novyi mir, (9), 196-227.

39. Tetaz J.-M. (2012). Narativnaia identichnost' kak teoriia prakticheskoi sub'ektivnosti: k rekonstruktsii kontseptsii Polia Rikera [Narrative identity as a theory of practical subjectivity: An essay on reconstruction of Paul Ricoeur's theory]. Sociological review, 11(2), 100-121. 
40. Timenchik R.D. Anna Akhmatova v 1960-e gody [Anna Akhmatova in the 1960-s]. M.; Toronto: Aquarius Publishers; The University of Toronto, 2005.

41. Tiurina I.I. (2006). Poetika otrazhenii v lirike A. Akhmatovoi ("Severnye ellegii", "Polnochnye stikhi") [Poetics of reflections in A. Akhmatova's lyrics ("Northern elegies", "Midnight verses")]. Tomsk State Pedagogical University Bulletin, (8), 93-98.

42. Tolstoy L.N. OShekspire io drame [About Shakespeare and the drama]. In: Tolstoy L.N. Sobranie sochinenii v 22 t. T. 15. (Collection of works in 22 vol. Vol. 15). Moscow: Khudozhestvennaia literature, 1983.

43. Toporov V.N., Tsiv'ian T.V. (1990). Nervalianskii sloi u Akhmatovoi i Mandel'shtama (ob odnom podtekste akmeizma), Novo-Basmannaia, 19 [Nervalian layer in Akhmatova's and Mandelstam's works (on one implication of acmeism)]. Novo-Basmannaya, 19, 420-447.

44. Tsiv'ian T.V. (1989). Kassandra, Didona, Fedra. Antichnye geroini - zerkala Akhmatovoi [Cassandra, Dido, Phaedra. Antique heroines - the mirrors of Akhmatova]. Literaturnoe obozrenie, (5), 29-33.

45. Tsiv'ian T.V. Semioticheskie puteshestviia [Semiotic travels]. St.-Petersburg: Publishing house of IVAN LIMBAKH, 2001.

46. Turgenev I.S. Gamlet $i$ Don-Kikhot [Hamlet and don Quixote]. In: Turgenev I.S. Polnoe sobranie sochinenii i pisem v 30 t. Sochineniia v 12 t. T. 5 (A full collection of works and letters in 30 volumes. Works in 12 volumes. Vol. 5). Moscow: Nauka, 1980.

47. Volkov S. Dialogi s Iosifom Brodskim [Conversations with Joseph Brodsky]. Moscow: Nezavisimaia gazeta, 2000.

48. Vygotsky L.S. Tragediia o Gamlete, printse Datskom, U. Shekspira [The Tragedy of W. Shakespeare's Hamlet, Prince of Denmark]. In: Vygotsky L.S. Psikhologiia iskusstva [The art of psychology]. Moscow: Pedagogika, 1987. Pp. 251-291.

49. Zapisnye knizhki Anny Akhmatovoi (1958 - 1966) [Anna Akhmatova's notebooks. (1958-1966) (1996). Moscow - Torino: Giulio Einaudi editore, 1996.

50. Zholkovskii A.K., Panova L.G. Pesni zhesty muzhskoe zhenskoe. K poeticheskoi pragmatike Anny Akhmatovoi. Ot slov k telu: Sbornik statei k 60-ti letiiu Iu. Tsiv'iana [Songs gestures masculine feminine. To Anna Akhmatova's poetic pragmatics. From words to body: Collection of articles to the 60th anniversary of Iu. Tsiv'ian]. Moscow: Novoe literaturnoe obozrenie, 2010. Pp. 50-71. 


\section{Читающая Ахматова: \\ на пути к обретению самости}

Г.Н. Михайлова

Вильнюсский университет

3 Университетская ул., Вильнюс, LT-01513, Литва

В статье в рамках теории чтения П. Рикёра на примере раннего стихотворения Аннь Ахматовой "Читая “Гамлета"» рассматривается литературное решение проблемь самоидентификации, которое позволяет говорить о «повествовательной идентичности» поэта. Анализ ахматовской рефигурации и исследование названной стихотворной конфигурации показали стремление поэта достичь самости путем обозначения жизненного мира шекспировским текстом. Статья включает в себя сопоставление культурных смыслов, вложенных в персонажей трагедии Шекспира (Офелии и Гамлета) русскими и европейскими читателями - предшественниками и современниками Ахматовой. Особое внимание уделяется возможной идентификации Ахматовой с одним из персонажей европейского культурного поля - Элизабет Сиддал (Elizabeth Siddal) и ее вымышленному изображению себя в качестве шекспировской Офелии. Интерполируя отдельные значения прочитанных и истолкованныхх культурных текстов на предикаты собственной жизненной ситуачии 1903-1912 г2., Ахматова, прежде всего, проясняет свои взаимоотношения с Николаем Гумилевым и решает проблему сохранения собственной идентичности.

Ключевые слова: Ахматова, Гумилев, Гамлет, Офелия, Россетти (Rosetti), Сиддал (Siddal), Рикёр (Ricoеur), идентичность, жизненный мир.

Научная специальность: 10.00.00 - филологические науки. 